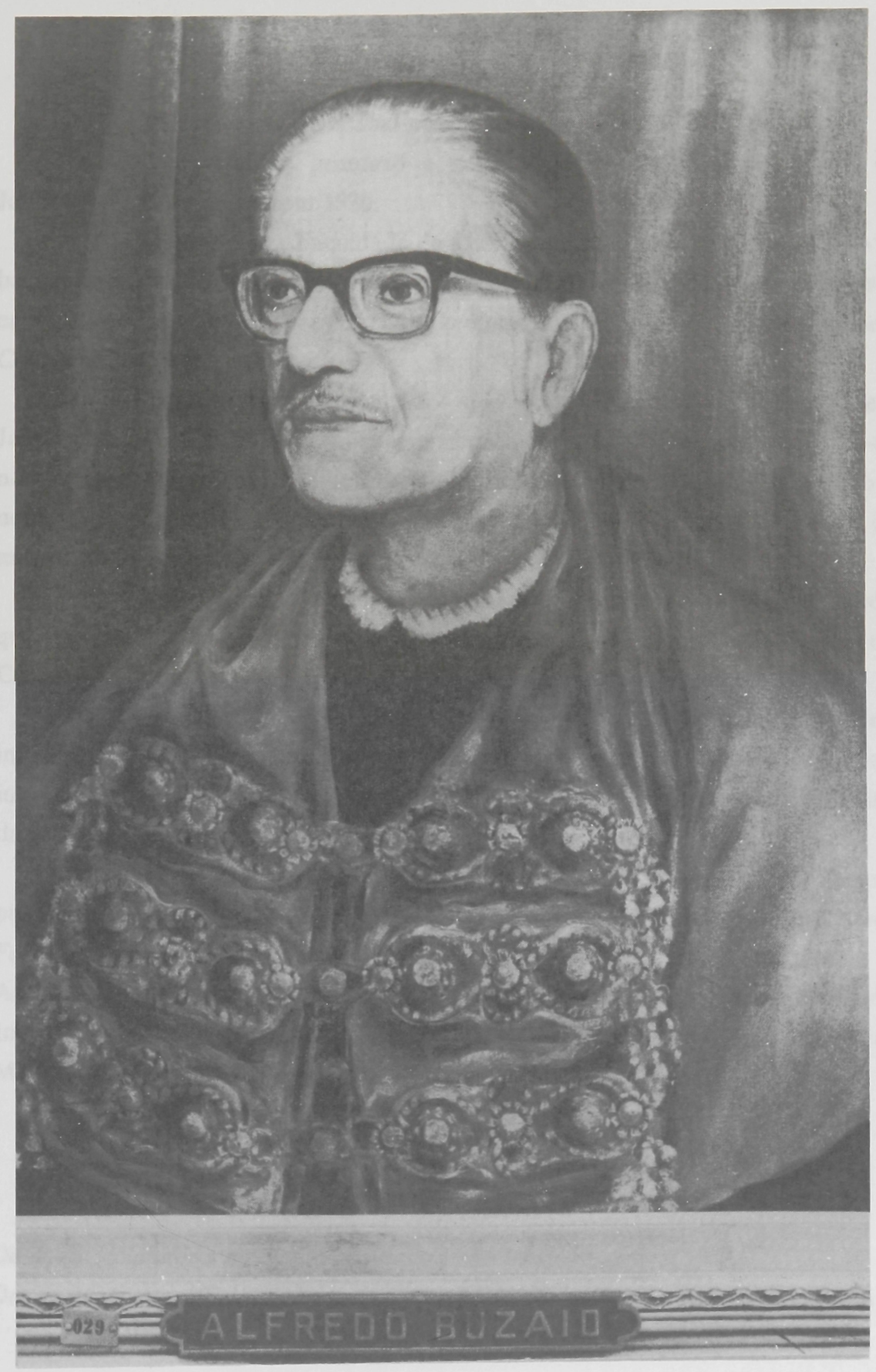





\section{ALFREDO BUZAID}

(1967-1969)

Nasceu em Jaboticabal no dia 20 de julho de 1914.

Fez o curso primário e secundário no Ginásio São Luiz, de Jaboticabal, formando-se em 1930.

Ingressou na Faculdade de Direito de São Paulo em 1931, tendo se bacharelado em 1935. Manifestando inclinação para as letras desde os primeiros estudos, escreveu para o periódico $O$ Combate, de Jaboticabal e para a Gazeta Comercial, da qual foi diretor.

Logo após a conclusão do curso acadêmico, advogou em Jaboticabal até 1938, quando transferiu-se para São Paulo. Em 1945 inscreveu-se no concurso à livre-docência de Direito Judiciário Civil, tendo sido aprovado e nomeado em agosto de 1946. Em 1957 inscreveu-se no concurso à cátedra da mesma disciplina, sendo aprovado e nomeado em maio de 1958.

Foi secretário geral do Instituto de Direito Processual Civil, sendo que em janeiro de 1964, apresentou ao ministro da Justiça o anteprojeto do Código de Processo Civil Brasileiro, transformado posteriormente em projeto.

De 1967 a 1969 foi diretor da Faculdade de Direito, assumindo no início de 1969, a vice-reitoria da Universidade de São Paulo. Ocupou interinamente a Reitoria e, em novembro do mesmo ano, foi nomeado ministro da Justiça do Governo Médici, aí permanecendo até 1974.

Participou de diversas conferências no Brasil e no exterior; publicou vários pareceres e artigos de doutrina na Revista dos Tribunais, Revista Forense, Revista da Faculdade de Direito e na Revista Jurídica. Pertenceu à Associação Italiana de Processo Civil, com sede em Florença, foi membro do Instituto Ibero-Luso-Filipino e Americano de Processo Civil, com sede em Madri, e Conselheiro da Revista de Derecho Procesual Civil.

Faleceu a 09 de julho de 1991.

\section{Obras Publicadas}

Da ação declaratória no direito brasileiro. São Paulo : Saraiva, 1943.

Da apelação ex officio no sistema do código de processo civil. São Paulo : Saraiva, 1951. 
Da ação direta de declaração de inconstitucionalidade no direito brasileiro. São Paulo : Saraiva, 1958.

Rumos políticos da revolução brasileira. Brasilia : Ministério da Justiça, 1970.

Marxismo e Cristianismo: o problema do ateísmo. Brasília : Ministério da Justiça, 1970.

Da conjuntura política nacional. Brasília : Imprensa Nacional, 1972.

Estudos de direito. São Paulo : Saraiva, 1972.

José Bonifácio: a visão do estadista. Rio de Janeiro : Imprensa Nacional, 1972.

Humanismo político. Brasília : Ministério da Justiça, 1973.

Atualidade de Rui Barbosa. Rio de Janeiro : Imprensa Nacional, 1973.

Grandes processualistas. São Paulo : Saraiva, 1982.

$\mathrm{Da}$ ação renovatória e das demais ações oriundas de contrato de locação de imóveis destinados a fins comerciais. $3^{a}$ ed. rev. e aum. São Paulo : Saraiva, 1957.

Do mandado de segurança. São Paulo : Saraiva, 1989-.

Considerações sobre o mandado de segurança coletivo. São Paulo : Saraiva, 1992 (obra póstuma). 